\title{
O LIRISMO NO LIMITE: A CRÔNICA DE Rubem Braga e Paulo Mendes Campos
}

\author{
Lyricism on the edge: Rubem Braga and Paulo \\ Mendes Campos's cronicles
}

\author{
Gabriela Kvacek Betella*
}

Se o indivíduo entrou em crise e a literatura pôde expressá-la, a lírica soube incorporar de modo requintado o ajuste necessário para a representação da realidade, ainda que suas características essenciais comportassem primeiro a expressão individual. Theodor Adorno destaca aspectos do "vigor coletivo da lírica contemporânea" contrapondo-os aos da lírica tradicional, com o cuidado de averiguar a relação entre as manifestações individuais do sujeito e o sentido coletivo dos aspectos sociais manifestados no gênero lírico. ${ }^{1} \mathrm{O}$ sujeito poético "sempre representa um sujeito coletivo muito mais universal" e mantém uma relação "com a realidade social que lhe é antitética", o que exige da interpretação muito mais que a análise dos elementos formais do texto, pois a matéria social pede elucidação, na medida em que está incorporada na composição, assim como o seu tempo histórico. ${ }^{2}$

Os gêneros ultrapassaram vários de seus limites, e a análise literária passou a utilizar abertamente, entre outros termos, a expressão lirismo em prosa. A crônica brasileira recebeu esse tratamento em competentes momentos da crítica, capazes de ressaltar o valor da subjetividade a filtrar o momento cotidiano. Alguns cronistas são hábeis em promover nas composições a permanência de um fato (retirado ou não da memória), revirando a substância de seu tempo e, simultaneamente, escapando da passagem dos anos. ${ }^{3}$ Falar dos gêneros híbridos - crônica, epistolografia, diário, memória - significa, em poucas palavras, referir-se a

\footnotetext{
USP

ADORNO, Theodor W. Palestra sobre lírica e sociedade. In: Notas de Literatura I. Trad. Jorge Almeida. São Paulo: Duas Cidades/Ed. 34, 2003. p. 65-89.

$2 \quad$ Ibid., p. 78

3 ARRIGUCCI Jr., Davi. Fragmentos sobre a crônica. In: Enigma e comentário ensaios sobre literatura e experiência. São Paulo: Companhia das Letras, 1987. p. 53.
} 
BETELLA, G. K. O LiRISMO No LIMITE...

escritos que misturam notícia e literatura, mantendo o caráter fragmentário como uma característica estrutural, bem como a "escrita do eu" pode ser a expressão que define melhor esses gêneros, em todos os tempos.

Desde suas origens, crônicas são como reportagens subjetivas. Toda "notícia" pode ser um bom pretexto para reflexões do cronista. A linguagem apela para o gosto, para as impressões, comentários e caprichos pessoais a partir da novidade em questão. Há um "eu" fortalecido graças à perspicácia aplicada ao calor da hora, facilitando a ligação entre a voz que narra e o cronista que a compõe. O narrador da crônica é alguém extremamente atento e capaz de captar a realidade que o circunda, para logo em seguida julgá-la, expressando o julgamento no discurso. Tal procedimento pode ser exatamente o do cronista, e o relato por vezes tão sincero tem tudo para configurar uma narrativa pessoal, e o leitor concluirá que o escritor, na sua versão cronista, tem exatamente aquela visão de mundo, embora seja possível fazer uma suposição que pode colocar sob questão o grau de subjetividade da crônica: não poderia o cronista estar criando uma posição de observação ficcional a partir da qual pudesse comentar o seu presente, construir uma imagem deste e julgá-lo de acordo com essa perspectiva fictícia e, sem dúvida, compactuada com algum elemento da realidade observada? A hipótese traz à tona uma série de considerações sobre a construção do foco narrativo, importantes para a investigação formal.

Se, por um lado, a prosa moderna transitou entre subjetividade e objetividade, isto é, se ela desenvolveu modalidades para o foco narrativo que culminaram no discurso indireto livre e no esfacelamento da onisciência do narrador, a crônica nunca abriu mão da subjetividade. A partir do século XIX, romances, novelas e contos passaram a misturar várias modalidades de discurso (e de foco narrativo) num mesmo texto, como também explicitaram o desconforto da fragmentação e da perda do centro, da perspectiva e do mimetismo artísticos, criadores da ilusão do absoluto. A provocação intensa da "objetivização" da visão realista sobre uma realidade cada vez mais caótica detonou a crise do gênero romanesco, as inovações formais deste e as teorizações para o acompanhamento dos fenômenos. Enquanto isso, a crônica intensificava a presença da vivência subjetiva na narração dos dados objetivos (até da manchete do dia), na sua expressão do mundo narrado. A representação esclarecidamente realista recebe musculatura com a valorização da subjetividade pelo texto literário.

$\mathrm{Na}$ prosa moderna, o "preceito épico da objetividade [Gegenständlichkeit]" ${ }^{4}$ é inaceitável. Em nossos tempos, a composição literária representa a impossibilidade do domínio de tantos apelos da

4 ADORNO, T. W. op. cit., p. 55. 
realidade. A subjetividade desenvolvida pela narrativa moderna converteu o relato a um contrário da narrativa clássica e fez dele um testemunho da situação do indivíduo que liquida a si mesmo nesses tempos em que não se pode mais garantir o mundo cheio de sentido. No âmbito textual, a subjetividade, aliada à simplicidade e pureza da linguagem, leva o leitor a co-realizar algo já realizado, como se estivesse presente na ação. Assim como as outras formas de ficção, a crônica moderna também tem um pacto com o desvelamento do real, e é capaz de trazer na própria forma a precariedade da perspectiva absoluta e ilusória junto com o requinte da execução de um "não-saber" muito mais eficaz no conhecimento do mundo.

A proposta aqui é tanto introduzir características de uma fase da crônica brasileira quanto comparar aspectos de dois cronistas. O gênero, praticado em nossa imprensa desde o século XIX, aproveita um grande momento nos anos de 1950 e desfruta da cidade do Rio de Janeiro como espaço preferencial. Por essas razões, temos que nos transportar para o contexto que abrigou um cenário cultural incomparável. Antes de deixar de ser capital do Brasil, com a inauguração de Brasília em 1960, o Rio de Janeiro vivera o que talvez tenha sido o melhor em termos de lazer, divertimento e ostentação, centralizando em seu espaço territorial uma série de acontecimentos lembrados em vários relatos de hoje como a época em que tudo parecia dar certo.

Ao longo da década de 1950, a sociedade brasileira afirmava seu caráter urbano e industrial, com sensíveis alterações no comportamento da população, especialmente no que diz respeito ao consumo. Um novo estilo de vida doméstica se impunha, com a invasão dos eletrodomésticos, dos plásticos e das fibras sintéticas, vendendo a ideia de praticidade e baixo custo. O comportamento urbano reflete o estilo norte-americano. A televisão chegava ao Brasil nesse tempo, com certo ar de alienação, enquanto outras manifestações culturais, como o cinema e o teatro, buscavam a renovação estética acompanhada da discussão de questões políticas e sociais. Mas o país saboreou a invenção da bossa-nova e as comemorações da conquista da Copa do Mundo na Suécia em 1958, com vários personagens desfilando no imaginário das pessoas, como se protagonizassem crônicas da época (alguns protagonizaram, de fato): Garrincha, Oscar Niemeyer, Zé Trindade, Roberto Santos, Juscelino Kubitschek, João Gilberto, Adalgisa Colombo, Pelé, Carlos Eduardo Reidy, Amílcar de Castro, Emmanuel Vão Gôgo, Ibrahim Sued, Tom Jobim, Carlos Machado, Maysa, Flávio Cavalcanti, Luis Carlos Prestes, Falcão Negro, Cacilda Becker, Carlos Lacerda, Sacha Rubin, Maria Ester Bueno, Alziro Zarur, Aída Curi, Gianfrancesco Guarnieri, Amigo da Onça, Nelson Pereira dos Santos, Éder Jofre, Lúcio Costa, o rinoceronte Cacareco, os lotações, a pioneira escada rolante das lojas Sears, a Panair, as camisas Volta ao Mundo, a caneta Parker 61, o footing no calçadão de 
BETELLA, G. K. O LiRISMO No LIMITE...

Copacabana, o frescobol, a Romi-Iseta, os pentes Flamengo, o Repórter Esso, a TV Tupi, as certinhas do Lalau e, não menos importante, o padrão de beleza feminina que ignorava a ginástica, a dieta e permitia às mulheres que pesassem mais de 60 quilos. $^{5}$

De maneira geral, a crônica permite ao leitor o estabelecimento de afinidades entre a prosa e a poesia ou a filosofia, graças ao grau de subjetividade aliada à expressão capaz de definir fatos e sentimentos, fixando uma verdade para eles. A crônica recebe vários formatos, incorpora outros gêneros sem manifestar nenhuma preocupação com distinções. Talvez isso se deva ao fato de ser recebida no jornal, meio democrático que a deixa à vontade. Segundo Antonio Candido, no jornal a crônica acha-se num "meio nutritivo [...] entre crimes, inaugurações, anúncios, escândalos, fotografias, surpresas", em suma, com "todo o equipamento fugaz de cada dia", aliando força e fragilidade, razão pela qual (e aqui o crítico aponta um paradoxo) "o teste das crônicas é o livro, onde são recolhidas em fila, como capítulos, desligadas do meio original. Se permanecem boas e às vezes melhores que no jornal, está garantida a sua qualidade". ${ }^{6}$ A partir daí, o "esperado lanche em pé", ou a crônica lida no calor da hora, transforma-se em repasto oferecido como pensamento organizado ao longo das páginas do livro. Leitores de vários tempos podem examinar com mais cuidado a atitude, a filosofia de vida, a meditação sobre valores duráveis, sob os pretextos transitórios da crônica que, liberta do jornal, permanece no livro.

Assim como alguns de seus colegas cronistas (Drummond escrevia no Correio da Manhã de 1954 a 1969; Bandeira escreveu crônicas entre 1957 e 1961 para o Jornal do Brasil e para a Folha de S. Paulo, para citar somente dois exemplos), Paulo Mendes Campos havia publicado os textos do livro $O$ cego de Ipanema no Diário Carioca e na revista Manchete, entre 1946 e 1960. São crônicas selecionadas pelo autor e por Marlene de Castro Corrêa, e saem pela Editora do Autor, fundada naquele 1960 por Fernando Sabino, Rubem Braga e Walter Acosta. A partir de agosto de 1953, Paulo assina a coluna "Conversa literária" na Manchete, e dali sairá boa parte do material dos próximos livros. É possível notar temas preferenciais, que pontuarão a obra em crônica de Paulo Mendes Campos e, considerando esses temas, vale a pena escolher alguns exemplos para análise. Além das manifestações do humor, podemos ver textos dedicados à complexidade da figura do brotinho, à prosa poética, aos poemas em prosa, tratando de diversos assuntos, inclusive o modo ideal para se passar os domingos, na "Receita de domingo":

\footnotetext{
5 SANTOS, Joaquim Ferreira dos. 58 vezes 58. In: devia terminar. 5. ed. Rio de Janeiro: Record, 1998. p. 173-187.

6 CANDIDO, Antonio. Dois cronistas. In: Feliz 1958: o ano que não Duas Cidades; Ed. 34, 2002. p. 208. Textos de intervenção. São Paulo:
} 
Ter na véspera o cuidado de escancarar a janela. Despertar com a primeira luz cantando e ver da moldura da janela a mocidade do universo, límpido incêndio a debruar de vermelho quase frio as nuvens espessas. A brisa alta, que se levanta, agitar docemente as grinaldas das janelas fronteiras. Uma gaivota madrugadora cruzar o retângulo. Um galo desenhar na hora a parábola de seu canto. Então, dormir de novo, devagar, como se dessa vez fosse para retornar à terra só ao som da trombeta do arcanjo.

Café e jornais devem estar à nossa espera no momento preciso no qual violentamos a ausência do sono e voltamos à tona. Esse milagre doméstico tem de ser. Da área subir uma dissonância festiva de instrumentos de percussão - caçarolas, panelas, frigideiras, cristais - anunciando que a química e a ternura do almoço mais farto e saboroso não foram esquecidas. Jorre a água do tanque e, perto deste, a galinha que vai entrar na faca saia de seu mutismo e cacareje como em domingos de antigamente. Também o canário belga do vizinho descobrir deslumbrado que faz domingo.

$[\ldots]$

Se a Aeronáutica não se dispuser esta manhã a divertir a infância com os seus mergulhos acrobáticos, torna-se indispensável a passagem de sócios da Hípica, em corcéis ainda mais kar do que os próprios cavaleiros.

Comprar para a meninada tudo que o médico e o regime doméstico desaconselham: sorvetes mil, uvas cristalizadas, pirulitos, algodão doce, refrigerantes, balões em forma de pingüim, macaquinhos de pano, papaventos. Fingir-se de distraído no momento em que o terrível caçula, armado, aproximar-se da barraca onde dorme o imenso alemão para desferir nas costas gordas do tedesco uma vigorosa paulada. A pedagogia recomenda não contrariar demais as crianças.

No instante em que a meninada já comece a "encher", a mulher deve resolver ir cuidar do almoço e deixar-nos sós. Notar, portanto, que as moças estão em flor, e o nosso envelhecimento não é uma regra geral.

[...]

Novamente em casa, conversar com a família. Contar uma história meio macabra aos meninos. Enquanto estes são postos em sossego, abrir um livro. Sentir que a noite desce e as luzes distantes melancolizam. Se a solidão assaltar-nos, subjugá-la; se o sentimento de insegurança chegar, usar o telefone; se for a saudade, abrigá-la com reservas; se for a poesia, possuí-la; se for o corvo arranhando o caixilho da janela, gritar-lhe alto e bom som: never more.

Noite pesada. À luz da lâmpada, viajamos. O livro precisa dizernos que o mundo está errado, que o mundo devia, mas não é composto de domingos. Então, como uma espada, surgir da nossa 
BETELLA, G. K. O LiRISMO No LIMITE...

felicidade burguesa e particular uma dor viril e irritada, de lado a lado. Para que os dias da semana entrante não nos repartam em uma existência de egoísmos. ${ }^{7}$

O texto poderia ser classificado como uma espécie de teoria aplicada ao cotidiano da pessoa comum. A crônica exerce o potencial de discussão sobre o gênero a partir da própria forma, cuja fluidez se deve basicamente à presença do cronista (o "eu") e ao conteúdo bastante familiar ao leitor. Na "Receita de domingo" de Paulo Mendes Campos, a linguagem apresenta uma habilidade especial ao ser alçada a linguagem poética sem deixar de manter os elementos coloquiais, de modo a representar a banalidade de um domingo. Veja-se o fragmento: “Jorre a água do tanque e, perto deste, a galinha que vai entrar na faca saia de seu mutismo e cacareje como em domingos de antigamente. Também o canário belga do vizinho descobrir deslumbrado que faz domingo." o que se percebe é um cuidadoso manejo do tempo verbal (imperativo - futuro - imperativo - infinitivo - presente), imprimindo certeza aos acontecimentos, sem deixar dúvidas sobre a ocorrência desses detalhes, dispostos nas frases de modo a perpetuar um passado conhecido (a galinha deve cacarejar como nos domingos de antigamente) no presente rotineiro da última frase do fragmento, marcada pela fala coloquial (precisamos "encenar" a frase em voz alta para perceber como falamos assim) incorporada ao texto com o pequeno requinte assonante ("descobrir deslumbrado que faz domingo").

o texto recolhe o máximo de referências para construir o domingo ideal e, mais que isso, para reivindicar o direito aos prazeres mais cotidianos, independentemente de sua qualidade estética ou de salubridade, como se o domingo devesse ser o tempo ideal para que todas essas regalias pudessem ser vividas, uma seguida da outra. Fazendo da crônica uma espécie de "educação física e sentimental", a linguagem de Paulo é delicada como deveria ser nossa atitude diante das imagens oferecidas pelo dia ("Despertar com a primeira luz cantando e ver da moldura da janela a mocidade do universo, límpido incêndio a debruar de vermelho quase frio as nuvens espessas"). Além de projetar para a ideia de domingo ideal as lembranças de domingos do passado, a crônica resgata a miudeza doméstica vivenciada por qualquer um ("Da área subir uma dissonância festiva de instrumentos de percussão - caçarolas, panelas, frigideiras, cristais - anunciando que a química e a ternura do almoço mais farto e saboroso não foram esquecidas”). O cronista nos prova que a crônica pode mergulhar em qualquer dimensão do tempo e voltar à tona, com a mesma vivacidade. E também pode manter Janeiro: Editora do Autor, 1960. p. 41-44.

O cego de Ipanema. Rio de 
expressões datadas, como é o caso de "kar" ("torna-se indispensável a passagem de sócios da Hípica, em corcéis ainda mais kar do que os próprios cavaleiros"), à maneira de Jacinto de Thormes. ${ }^{8}$

A crônica espera do leitor os atos mais grandiosos para a solução de problemas tipicamente dominicais. O maior desses problemas é o fato de o mundo não ser composto de domingos, e é a realidade a ser enfrentada, com coragem e, principalmente, confiança na capacidade de compartilhar os dias com os outros ("Para que os dias da semana entrante não nos repartam em uma existência de egoísmos").

Ao escolher um tema tão afinado com a condição do homem comum, a crônica é capaz de promover uma transfiguração, graças à simplicidade das imagens e aos refinados recursos de linguagem que emprega, provando que um discurso aparentemente trivial pode conter um sentido para as possibilidades da existência num tempo e num espaço em que o homem é forçado a não se deslumbrar com o singelo e a se destruir com o tédio. Nesse sentido, o grau de subjetividade expressada no texto de Paulo alcança algo além das emoções e das experiências individuais. Talvez por isso Antonio Candido tenha preferido utilizar a definição de "larga onda

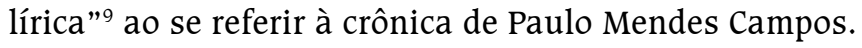

Um dos primeiros textos da coletânea $O$ cego de Ipanema traz um tema caro ao escritor: a beleza jovem e feminina, das moças em flor, provando que "nosso envelhecimento não é uma regra geral", aliada à espontaneidade de que se serve o próprio autor, ao descrever o "brotinho":

Ser brotinho é não usar pintura alguma, às vezes, e ficar de cara lambida, os cabelos desarrumados como se ventasse forte, o corpo todo apagado dentro de um vestido tão de propósito sem graça, mas lançando fogo pelos olhos. Ser brotinho é lançar fogo pelos olhos.

É viver a tarde inteira, em uma atitude esquemática, a contemplar o teto, só para poder contar depois que ficou a tarde inteira olhando

$8 \quad$ Jacinto de Thormes (1923-2005) era o pseudônimo de Maneco Müller, pioneiro do colunismo social no Brasil. Na década de 1950, assinava sua coluna no jornal carioca Correio da Manhã. o jornalista também trabalhou no Diário Carioca e no Última Hora. Terminava muitas de suas notas com o mote "Depois eu conto". Filho de família tradicional, com alguns embaixadores no parentesco, estudou no exterior, e era considerado uma figura charmosa, elegante e educada. Para se tornar colunista exigiu o pseudônimo que homenageava a personagem de Eça de Oueiroz. Anos mais tarde, deixou a coluna social e passou a escrever comentários sobre futebol. A coluna de Ibrahim Sued, também nascida nessa época de florescimento do gênero, dividia e disputava com a de Jacinto de Thormes os "furos", os leitores e algumas expressões, como é o caso de "kar". A palavra sintetiza a ostentação típica daqueles anos no universo carioca, apelando para um dos sentidos do vocábulo como elemento de composição, a saber, relacionado ao alto valor atribuído à coisa. das Letras, 1993. p. 29. Recortes. São Paulo: Companhia 
BETELLA, G. K. O LiRISMO No LIMITE...

para cima, sem pensar em nada. É passar um dia todo descalça no apartamento da amiga comendo comida de lata e cortar o dedo. Ser brotinho é ainda possuir vitrola própria e perambular pelas ruas do bairro com um ar sonso-vagaroso, abraçada a uma porção de elepês coloridos. [...]

Ser brotinho é poder usar óculos como se fosse enfeite, como um adjetivo para o rosto e para o espírito. É esvaziar o sentido das coisas que transbordam de sentido, mas é também dar sentido de repente ao vácuo absoluto. [...]

[...] Eventualmente, ser brotinho é como se não fosse, sentindo-se quase a cair do galho, de tão amadurecida em todo o seu ser. É fazer marcação cerrada sobre a presunção incomensurável dos homens. Tomar uma pose, ora de soneto moderno, ora de minueto, sem que se dissipe a unidade essencial. É policiar parentes, amigos, mestres e mestras com um ar songamonga de quem nada vê, nada ouve, nada fala. ${ }^{10}$

O despojamento aliado à graça particular do brotinho, a casualidade calculada para reter somente a aparência acidental, $o$ ar sonso que pode esconder um plano, e todas as definições de atitudes da "idade em flor" são fragmentos que se complementam para oferecer a noção de partes de um todo distribuído entre as moças que povoavam a cidade. Visto por outro ângulo, e forçando a nota para demonstrar uma incorporação de conteúdo na forma, o texto pode ser alçado à definição das principais diretrizes e efeitos da crônica, em meio a um jogo metafórico entre a figura do brotinho e o gênero situado em meio às indefinições literárias.

Há no mesmo volume duas outras crônicas cujo tema é a meninamoça. São textos circunstanciados, não mais "crônica-teoria", como o anterior:

Como é difícil, como é desmesuradamente difícil ser brotinho. Uma santa à beira do pecado, artista de circo com uma vontade de rir lá do alto, uma menina de primeira comunhão, depois nuinha dentro dum pesadelo animado.

[...] Estirada na colinazinha de areia, quem a olha, olha de verdade. Por alguns momentos sente-se olhada mesmo, completamente mulher. Dói um bom dentro dela. Mas vai pular dentro da bóia, e pronto: mal se aconchegou, já é menina. Menina, mulher, menina. Raiva da mãe que a espia de longe: no mar, medo que se afogue; em terra, que se enamore. Mas o ódio grande é daquele alfinete de 
segurança com que a mãe prende o maiô nas costas. Melhor nem vir na praia. À praia. Uma cólera juvenil é tão impetuosa que se desfaz em compaixão desamparada. Queria e devia naquele momento morrer por sua mãe. [...]

Debaixo do chuveiro, esfomeada, feliz, como se, depois, fosse um baile. Se fecha os olhos, fica meio tonta e vê uma porção de outros olhos (olhos d'homem) pregados nela. [...] Enxuga-se, espalha talco pelo corpo cheio de ossos a brigar com a carne, vem chegando uma tristeza-pensamento: assim lavada, fico com um cheiro de menina tão pequena. Mas no quarto da cozinheira corrige o aroma da inocência com um pouco de perfume nacional, e corre para a mesa. - Que é isto, menina?

- Perfume, Madame, sabe o que é perfume?

- Pois vai lavar essa droga e troca de vestido imediatamente. Que fedor de mulher ordinária!

- Fedor?! De mulher ordinária, mãe?!

Perdeu a fome e começou a chorar sem pressa as mais vagarosas lágrimas de seus olhos. ${ }^{11}$

A história da menina que volta da praia, onde esteve com a mãe, aprofunda o retrato do brotinho para além da bela visão de uma passante. Criam-se algumas aferições psicológicas sobre o conturbado período em que a menina quer ultrapassar a condição infantil, de várias formas, sob inevitáveis movimentos conscientes e inconscientes. Primeiro, o cronista utiliza as imagens de primeira comunhão e de nudez em pesadelo, para explorar os campos da realidade e do sonho, e misturá-los, bem como promover o contraste entre inocência e sexualidade - essa é a pontuação da crônica, até o final. Em seguida, insere o elemento novo: a presença repreensiva da mãe, à distância ou mesmo ausente. Com sutileza, a crônica explora dados do início de uma relação conturbada e difícil (esta sim "desmesuradamente difícil”), movida pelas preocupações da mãe de adolescente menina e pelas descobertas desta. Através das sutilezas da linguagem e da utilização de imagens, o cronista denuncia algumas fraquezas. A mãe não contempla a filha, "espia", como se desconfiasse, à maneira das mães que não estabelecem uma relação de confiança com os filhos. O alfinete no maiô da garota, colocado pela mãe, é do mesmo tipo dos que se usavam nas antigas fraldas de pano. Com esta imagem, o cronista observa o cuidado de quem não atenta para a vaidade da filha: o maiô, como roupa de praia, deveria exibir sensualidade, e não arranjo malamanhado, muito menos semelhança forçada com as fraldas infantis. A mãe recusa o crescimento da filha.

11 CAMPOS, Paulo Mendes. Na praia. In o cego de Ipanema, op. cit., p. 
BETELLA, G. K. O LiRISMO No LIMITE...

Numa hábil demonstração do discurso, no fragmento "Melhor nem vir na praia. À praia", duas possibilidades de interpretação se desenham: a narrativa em terceira pessoa incorpora a autocorreção da menina como lembrança das correções da mãe sobre os deslizes gramaticais, ou somente relata a correção imposta pela própria personagem, na tentativa de sublimar mais um elemento infantil, no caso, na própria linguagem. Segue-se o retrato da confusão de sentimentos típica da idade e que, como fenômeno resultante da dura convivência entre entes queridos, provavelmente não vai se resolver tão facilmente: a menina odeia e, logo em seguida, se desfaz em compaixão pela mãe.

Com espantosa sensibilidade, o cronista explora um universo dificilmente alcançado pelos adultos próximos ao fenômeno brotinho. $O$ ponto alto do texto vem nas duas últimas cenas, a do banho e a do diálogo entre mãe e filha. A menina quer se desvencilhar da imagem de "menina tão pequena", mas esbarra na contundente ordem da mãe, que fere a poderosa descoberta do perfume vulgar como sinal de feminilidade, provavelmente pela associação com a sensualidade adulta da dona do perfume. A felicidade do banho, "como se, depois, fosse um baile", é arrematada pelo cheiro postiço (cuja nacionalidade não importa muito, como não importa a qualidade de tantos símbolos nessa fase da vida), que "corrige" a imagem olfativa e visual que precisa ser substituída. A mãe, não exatamente com preconceito, mas com medo, não pode perceber, entre uma grande quantidade de detalhes que reverberam nessa transformação da filha, que suas classificações não podem ser aplicadas aos impulsos que visualiza no corpo e nas atitudes da menina. Sem entender por que foi chamada de mulher ordinária, a menina chora, em meio à confusão entre o entendimento, a vergonha, a impotência, a raiva. Ela nem se lembra da sensação de ser olhada na praia, quando doía "um bom dentro dela".

É preciso acentuar o caráter de observador do cotidiano ostentado pelo cronista, condição do gênero desde os primórdios na imprensa brasileira. Na crônica de Paulo Mendes Campos, entretanto, a recriação quase poética de possíveis cenas de adolescente burguesa dos anos de 1950 nos faz refletir sobre conceitos sociais e psicológicos que ultrapassam esses limites. A visão do cronista busca sua impressão sobre os fatos, mas não deixa de ser guiada por uma reação à opressão que emana deles. Além disso, o incômodo não revelado explicitamente pelo discurso impregna-se nele e nos atinge de modo implacável.

Na terceira crônica cujo tema é o brotinho, além de marcar a recorrência do tema, o cronista se faz presente na cena: 
Desta vez eram três brotinhos dentro do lotação, duas horas radiantes de espaçosa tarde. Três brotinhos fazendo primavera no verão. Uma estalava nos seus quinze anos novinhos em folha; outra, embrulhada em papel para presente, ia fazer quinze; a terceira pulara dos quatorze, como o pinto amarelíssimo irrompe da casca em repentina manhã de antigamente.

Uma reluzia verde; o patinho preferia olhos azuis; a terceira consumia uma luz castanha e grave. Três brotinhos barrocos. Três quatis roendo avelãs, três sonetinhos com chave dourada, três auroras boreais no deslumbrante calor carioca.

Nós, cavalões, suávamos. As três gaivotas, sem saber se estava ainda quente, amanheciam. Nunca meus olhos viram nada mais fresco, limpo, inelutável. Eram lindas hortaliças de cores firmes espalhadas sobre o mármore.

$[\ldots]$

Três brotinhos irradiando luzes coloridas nesta cidade grossa. Dentro do lotação feio e vulgar. Acendi um cigarro como se parasse para tomar um caminho. Se ao menos eu soubesse compor no ar esses anéis de fumaça. No entanto, por esta luz que me alumia, não era preciso entender coisa nenhuma. De repente fez luar dentro do coche. Do alto de minhas velhas pirâmides, a beleza me contemplava. ${ }^{12}$

As meninas são descritas com imagens que traduzem delicadeza e suavidade. Nesse momento, a crônica nos remete ao Rubem Braga de $A$ traição das elegantes, e nos permite uma digressão:

Foi há muito tempo, no Mediterrâneo, ou numa praia qualquer perdida na imensidão do Brasil? Apenas sei que havia sol e alguns banhistas; e apareceram duas meninas de vestidos compridos - 0 de uma era verde, o da outra era azul. Essas meninas estavam um pouco longe de mim; vi que a princípio apenas brincavam na espuma; depois, erguendo os vestidos até os joelhos, avançaram um pouco mais. Com certeza uma onda imprevista as molhou; elas riam muito, e agora tomavam banho de mar assim vestidas, uma de azul, outra de verde. Uma devia ter 7 anos, outra 9 ou 10; não sei quem eram, se eram irmãs; de longe eu não as via bem. Eram apenas duas meninas vestidas de cores marinhas brincando no mar; e isso era alegre e tinha uma beleza ingênua e imprevista. Por que ressuscita dentro de mim essa imagem, essa manhã? Foi um momento apenas. Havia muita luz, e um vento. Eu estava de pé na praia. Podia ser um momento feliz, e em si mesmo talvez

111-113. o cego de Ipanema, op. cit., p. 
BETELLA, G. K. O LiRISMO No Limite...

fosse; e aquele singelo quadro de beleza me fez bem; mas uma fina, indefinível angústia me vem misturada com essa lembrança. $O$ vestido verde, o vestido azul, as duas meninas rindo, saltando com seus vestidos colados ao corpo, brilhando ao sol; o vento...

Eu devia estar triste quando vi as meninas, mas deixei um pouco minha tristeza para mirar com um sorriso a sua graça e a sua felicidade. Senti talvez necessidade de mostrar a alguém - "veja, aquelas duas meninas..." Mostrar à toa; ou, quem sabe, para repartir aquele instante de beleza como quem reparte um pão, ou um cacho de uvas em sinal de estima e de simplicidade; em sinal de comunhão; ou talvez para disfarçar minha silenciosa angústia.

Não era uma angústia dolorosa; era leve, quase suave. Como se eu tivesse de repente o sentimento vivo de que aquele momento luminoso era precário e fugaz; a grossa tristeza da vida, com seu gosto de solidão, subiu um instante dentro de mim, para me lembrar que eu devia ser feliz naquele momento, pois aquele momento ia passar. Foi talvez para fixá-lo, de algum modo, que pedi a ajuda de uma pessoa amiga; ou talvez eu quisesse dizer alguma coisa a essa pessoa e apenas lhe soubesse dizer: "veja aquelas duas meninas..."

E as meninas riam brincando no mar. ${ }^{13}$

Os dois cronistas se servem das imagens vivas de "beleza ingênua e imprevista" para explorar o efeito de alumbramento (explorado por Manuel Bandeira através da mesma dimensão cotidiana em seus poemas). Além disso, o contraste entre a graciosidade das meninas e a amargura dos observadores é traduzido para o desejo de comungar a visão com alguém por Rubem Braga, e para uma angústia "leve, quase suave", para "o sentimento vivo de que aquele momento luminoso era precário e fugaz". Então o cronista se vê entre "a grossa tristeza da vida" e a necessidade de fixar um momento tão precioso, o que é feito, sob o código salvador que restabelece o contato entre as pessoas. Para Rubem Braga, a aparição da beleza ingênua é motivo de ruptura com a solidão. Na escrita, o sujeito lírico “desamparado pelas musas", na expressão de Adorno ${ }^{14}$ refaz o caminho por si mesmo, traçando um percurso mais consciente, embora o resultado estético não deixe transparecer o motor racional.

Davi Arrigucci Jr. aponta o narrador rigoroso e preciso de fatos históricos na crônica de Carlos Drummond de Andrade, aproximando-o, por

13 BRAGA, Rubem. As meninas. In: ___ A traição das elegantes. 5. ed. Rio de Janeiro: Record, 1998. p. 76-78. A primeira edição do volume é de 1967, e a crônica é de 1957, conforme as edições de BRAGA, Rubem. 200 crônicas escolhidas. Rio de Janeiro: Record.

14 ADORNO, T. W. Palestra sobre lírica e sociedade. In: ____. Notas de Literatura I, op. cit., p. 66. 
essa característica, a Manuel Bandeira: ambos são quase cronistas "à moda antiga", entretanto mantêm a mescla do histórico e do ficcional, "ao mesmo tempo em que uma poesia inesperada espia através dos fatos da memória". ${ }^{15}$ Rubem Braga aproveita justamente esse filão, vasculhando a poesia da vida diária e aproximando-a do leitor através do texto imitador do bate-papo. Em muitos textos desse cronista está indicada a metamorfose da prosa da crônica em lirismo, quando "tomada pela subjetividade de um poeta do instantâneo" que não abandona a simplicidade; em outros casos, a crônica acaba se confundindo com o conto, narrativa satírica ou confissão, por causa da objetivação e da elaboração dos níveis ficcionais. ${ }^{16}$ Algumas vezes, o discurso alia a esse tipo de composição uma crítica através da negação ou estranhamento da realidade observada pelo narrador e percebida pelo leitor graças à identificação.

Desde o início de sua carreira, as reportagens de Rubem Braga vinham impregnadas de sensibilidade. À medida que a crônica torna-se terreno definitivo, o autor conquista o direito de explorar em prosa imagens e sensações costumeiramente de exclusiva representação poética. Assim como Paulo, Braga parece ter sempre entendido que a essência da crônica deve ser o tratamento subjetivo, através da ótica sensível, cuja contribuição para o conjunto da produção literária brasileira prova a capacidade do texto de manter a verdade íntima com a qual penetra em seu mundo.

As narrativas dos dois cronistas misturam os procedimentos de antigas tradições da narrativa oral com a experiência do homem moderno, perplexo entre sentimentos autênticos e realidade absurda. Eles encontraram uma saída autenticamente literária, unindo a miudeza do cotidiano à expressividade que a conduz para o patamar lírico, embora escrevessem em boa prosa, em nome de conversa fiada. Noutras palavras, o discurso pode ser comparado à fala do velho contador de histórias, porque o narrador está interessado em relatar experiências de vida de todos os níveis (sentimentais, fantásticas, oníricas, sensuais, psicológicas, etc.) e, em tempos de consumo de informações rápidas, de experiências breves e mal vividas, esse tipo de narrativa resgata uma espécie em extinção na literatura: 0 narrador cuja sabedoria está fundada numa experiência comum ou compartilhada, instância consagrada por Walter Benjamin. A genialidade está na capacidade de atingir o leitor através do relato, das suas experiências vividas ou imaginadas. Esse aspecto mais próximo do ficcional, ou seja, a recriação objetiva do mundo e dos fatos através da narrativa em prosa, 
chega a aproximar a crônica, de modo paradoxal, do conto, da narrativa satírica e da confissão.

A simplicidade de expressão responde ao aprendizado pelo qual a crônica passou desde o século passado. Enquanto o conto permaneceu essencialmente preocupado com a construção formal para contar uma história de estrutura breve, sintética, exaltando seus elementos invariáveis, presos ao enredo, a crônica teve a sua qualidade multiplicada pelas variações de forma, de assunto, e pela arte de falar, por exemplo, da falta de assunto. Famosa é a crônica "Ao respeitável público", de 1934 (da época paulistana de Rubem Braga, quando trabalhou no Diário de São Paulo), publicada em O conde e o passarinho em 1936 (pela José Olympio - depois reeditada pela Editora do Autor, em 1961, pela Record, em 1982 e, a partir de então, sucessivamente nesta casa editorial). $O$ texto mais parece uma provocação ao leitor, em tom arrogante e até autodepreciativo, para falar das sensações de um cronista sem assunto para a coluna. Eis algumas passagens:

Chegou meu dia. Todo cronista tem seu dia em que, não tendo nada a escrever, fala da falta de assunto. Chegou meu dia. Que bela tarde para não se escrever!

Esse calor que arrasa tudo; esse carnaval que está perto, que aí vem no fim da semana; esses jornais lidos e relidos na minha mesa, sem nada interessante; esse cigarro que fumo sem prazer; essas cartas na gaveta onde ninguém me conta nada que possa me fazer mal ou bem; essa perspectiva morna do dia de amanhã; essa lembrança aborrecida do dia de ontem; e outra vez, e sempre, esse calor, esse calor, esse calor...

Portanto, meu distinto leitor, portanto, minha encantadora leitora, queiram ter a fineza de retirar os olhos desta coluna. Não leiam mais. Fiquem sabendo que eu secretamente os odeio a todos; que vocês todos são pessoas aborrecidas e irritantes; que eu desejo sinceramente que todos tenham um péssimo carnaval, uma horrível quaresma, um infelicíssimo ano em 1934, uma vida toda atrapalhada, uma morte estúpida!

[...] Fiquem sabendo que eu hoje tinha assunto e os recusei todos. ${ }^{17}$

Na obra de Rubem Braga, o desafio de restabelecer a dimensão das coisas é resolvido com a ajuda de uma fórmula muito bem manipulada que recebeu a prosa modernista, a tradição literária, a linguagem límpida, coloquial e correta, o ritmo falado. Daí a multiplicidade de enfoques, as inúmeras metamorfoses de Braga. Numa amostra de seus textos, podemos detectar polos - como o mundo urbano contraposto ao modo de viver do 
homem simples, de origem camponesa - que atraem o imaginário do autor e constituem as vias de entrada na substância da vida. As crônicas vão sendo definidas e mapeadas sorrateiramente, e o leitor permanece enredado pela linguagem - o que parece ser o propósito dos textos. $O$ elo entre as crônicas de Rubem Braga é a "temática da existência", e as indagações provocadas pela "narrativa da solidão" são marcantes.

São notáveis as crônicas que se utilizam do lirismo incontido e dos mitos particulares do autor, fundados sobre uma área limítrofe entre a observação do mundo (urbano, rural, degradado, miserável ou banal) e o imaginário. É como se a crônica quisesse dar conta das insuficiências da vida real. Nela se movem os mitos da mulher, da infância, da casa ideal, da solidão, da morte, sem esquecer os momentos de perseguição, do relato de um subversivo em época de ditadura ou de um representante de guerra. Vale observar que um desses tipos de relato pode conter os outros mitos, num amálgama que parece desejar mostrar todas as faces de uma realidade bem vivida, de emoções intensas e, para lucro dos leitores, verbalizadas na expressão cristalina. Assim, o sentimento aflitivo pode impregnar a narrativa de um deleite, e o prazer se interpõe nas descrições constrangedoras.

Na crônica "No lotação", de Paulo Mendes Campos, a visão das meninas estabelece um ponto de comparação com o meio ao redor delas, ao mesmo tempo em que o sujeito manifesta o devaneio, elemento caro a esse escritor. Enquanto as mocinhas parecem deslizar através dos gestos - "Três brotinhos barrocos. Três quatis roendo avelãs, três sonetinhos com chave dourada, três auroras boreais no deslumbrante calor carioca" -, a rusticidade do mundo permanece no ato enojadamente humano - "nós, cavalões, suávamos". A lembrança dos versos de Manuel Bandeira no "Rondó dos cavalinhos" - "Os cavalinhos correndo / E nós, cavalões, comendo" 18 - e do tom de comparação utilizado pelo poeta pernambucano (a delicadeza dos animais na pista do Jockey Club e a animalização das pessoas almoçando no restaurante) é inevitável. Paulo ainda contrapõe as meninas a gaivotas e hortaliças impecavelmente frescas, logo após a descrição dos descompostos, quase desfigurados "cavalões". Na visão do cronista, elas irradiavam "luzes coloridas" na "cidade grossa" e "dentro do lotação feio e vulgar". A expressão é de um autêntico eu-lírico, aqui diferenciado do narrador de Rubem Braga pelo anseio maior de expressão, em vez da partilha das impressões. Atordoado, só resta ao narrador de "No lotação" inverter as posições do ato da contemplação para aceitar a situação inusitada. Do alto das velhas crenças, hábitos, costumes, dúvidas e frustrações, a beleza (mais um fator a construir as pirâmides) o contemplava ou pedia para que ele a devorasse?

\footnotetext{
18 BANDEIRA, Manuel. Rondó dos cavalinhos. In: Estrela da vida inteira. 16 ed. Rio de Janeiro: José Olympio, 1989. p. 136.
} 
BETELLA, G. K. O LiRISMO No LIMITE...

Talvez nem uma coisa, nem outra, mas as duas. Analogamente, poderíamos propor uma questão para o lirismo que brota das crônicas examinadas neste estudo: trata-se de um caráter subjetivo ou objetivo? Se as impressões individuais serão sempre mediadas por um sentido social (e vice-versa), o efeito dos textos acima transcritos ultrapassa a comoção pelo sentimento de indivíduos isolados, pois através da constatação desse caráter subjetivo observamos nos mesmos textos reações contra os limites (ou contra formas de opressão morais e urbanas) do homem, como se o sentido da criação literária partisse da individualidade do ser que se vê estranho em meio à sociedade para atingir uma condição social (especialmente no sentido espiritual) superior. Assim, há algo de muito objetivo na operação artística dos dois cronistas estudados, pois os textos gritam por adeptos de uma qualidade de espírito, de memória, de delicadeza e de sensatez irrestrita. E, se o narrador de Rubem Braga costumeiramente se torna um aliado de seu leitor para enredá-lo no processo lírico, o narrador de Paulo Mendes Campos determina ocasiões para isso, como em "Receita de domingo", preferindo, em outros casos, uma impenetrável identificação entre eu-lírico e mundo narrado, que não deixa de ser humanizadora.

Ao longo de $O$ cego de Ipanema podemos notar verdadeiros textos poéticos em prosa, e Paulo é hábil em espalhar essa recriação híbrida para tratar de sentimentos e para emitir pareceres, tanto no nível sentimental quanto no nível analítico, de uma obra literária, por exemplo. Como um patamar não atrapalha o outro, eles se fazem interdependentes, a crônica resulta na expressão sincera da consciência do evento, seja ele problema grave, questão banal ou manifestação artística. O resultado é a emissão de um parecer com elementos críticos racionais e emoção:

Porque esse livro conta uma história que não ouvíramos ainda, que precisávamos ouvir, uma história que agora se torna impossível imaginar não existindo; porque devemos escutar uma história ao amanhecer, outra ao meio-dia, outra ao cair da noite; uma história na infância, outra ao abrir-se das luzes e das sombras da maturidade, outra quando um farol no golfo escuro decidir o caminho da velhice; porque há uma história no princípio, outra no meio, outra no fim do mundo; (...) porque esse livro repete a parábola da vida humana sobre a Terra e nos molha no frescor das primitivas vegetações terrestres, até aclarar-nos e ofuscar-nos em definitivas indagações da consciência; porque os homens são um único homem, e um único homem são todos os homens; porque Riobaldo esteve no Egeu, no castelo que preparava a guerra santa, na grande revolução libertária, no sertão de Minas entre os jagunços, e Riobaldo está a meu lado; porque a metafísica de Riobaldo percorre 
os tempos do mundo de ponta a ponta; porque Riobaldo é a ação que se contempla e o pensamento que sai armado cavaleiro.

$[\ldots]$ porque o pouco que sabemos esse livro ordena e nos ensina; porque o Brasil existe; porque os brasileiros existem; porque seguimos todos através do grande sertão, e aos poucos nos distinguimos no lusco-fusco do mato;

porque nós guardamos para sempre um livro como esse: eu o louvo com modéstia e espanto. ${ }^{19}$

Há muitas coisas que a psicologia não nos explica. Suponhamos que você esteja em um $12^{\circ}$. andar, em companhia de amigos, e, debruçando-se à janela, distinga lá embaixo, inesperada naquele momento, a figura de seu pai, procurando atravessar a rua ou descansando em um banco diante do mar. Só isso. Por que, então, todo esse alvoroço que visita a sua alma de repente, essa animação provocada pela presença distante de uma pessoa da sua intimidade? Você chamará os amigos para mostrar-lhes o vulto de traços fisionômicos invisíveis: "Aquele ali é papai." E os amigos também hão de sorrir, quase enternecidos, participando um pouco de sua glória, pois é inexplicavelmente tocante ser amigo de alguém cujo pai se encontra longe, fora do alcance do seu chamado. ${ }^{20}$

A matéria das duas crônicas acima é traduzida em espontaneidade pela linguagem e, ao receber uma ordenação quase instintiva das imagens, passa a ter reservada uma condição literária que deve sua existência à subjetividade e, num segundo passo, à comunhão entre o olhar do cronista e a recepção do leitor. Nos exemplos insinua-se na realidade representada algo de fantástico. Não se trata de uma circunstância de alumbramento, destacada nas crônicas cujo tema é o brotinho. $O$ extraordinário aparece fundido com o real, assim como o sujeito não se distingue mais em meio aos figurantes da crônica. Essas aproximações mostram o resultado da incorporação, no plano da forma, da identidade entre o mundo narrado e a voz que narra. Paulo Mendes Campos atravessava limites do texto, se fosse necessário, em busca de estruturas capazes de desarticular o texto para representar o inesperado. Através desses procedimentos, a crônica de Paulo prossegue, ainda nos anos de 1960, transitando livremente entre poesia e prosa, incorporando cada vez mais as estruturas móveis, mobilizando o estilo para aprofundar um inconformismo. Nesse sentido, a escrita fragmentária, bastante comum na crônica da época, torna-se característica

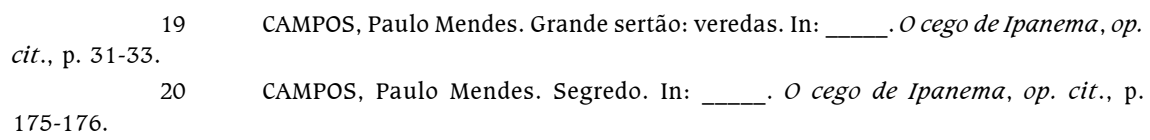


dos textos de Paulo, disposto a tornar a crônica uma obra aberta, representação de um mundo caótico.

Assim como acontece nas crônicas de Paulo Mendes Campos, e guardadas as particularidades de cada autor, Rubem Braga prova com sua operação lírica que sujeito e objeto podem ser fundidos em prosa. Sua linguagem exercita esse procedimento sem se contentar com o sentimentalismo, embora este apareça. A atmosfera confortável e aconchegante que pode surgir não chega a corromper o estilo elevado. $O$ narrador de Rubem Braga pode ser definido por uma espécie de saudosismo em inúmeras ocasiões, entretanto o seu enfoque é muito mais social do que individual. A preocupação em captar o detalhe cotidiano diminui em relação à preocupação com os problemas maiores que estão em jogo, que estão por trás da situação narrada. O sofrimento (e há muitas reflexões amargas na obra de Rubem Braga) não está na esfera individual. A denúncia social, equilibrada ao momento lírico, provoca efeitos contundentes no leitor. Aparecem na crônica os problemas de homens comuns, num país tão cheio de diferenças e de discrepâncias, como símbolos de riqueza convivendo ao lado de bondes lotados, ou como poesia que sobrevive em meio à culpa, à miséria, à corrupção. O narrador de Rubem Braga é habituado a saltar de um desses níveis a outro sorrateiramente (fugindo da reificação ou evitando o sentimental?), sem aviso para o leitor que, muitas vezes, termina uma crônica completamente atônito, porém mais humano. Na crônica de Paulo Mendes Campos e na de Rubem Braga, em cada uma a seu modo, a humanidade da representação parece estar salva.

\section{RESUMO}

Um dos fundamentos do gênero crônica é a subjetividade que transborda das histórias. Entre muitos cronistas atuantes no quadro da crônica brasileira nas décadas de 1950 e 1960 (as mais criativas no âmbito desse gênero literário, tanto no que diz respeito às nuances do humor quanto à sensibilidade mais íntima), destacam-se Rubem Braga e Paulo Mendes Campos, pelo alcance das impressões manifestadas no texto. O trabalho investiga alguns traços da operação lírica realizada pelos dois escritores em tempos cujas metas humanas divergem da matéria delicada e frágil. Ao valorizar justamente esses aspectos da vida e refletir sobre os novos sentidos deles, Paulo e Rubem redefinem o sentido da lírica moderna, ajustando seus procedimentos literários às crises do indivíduo e às modificações da expressão individual.

Palavras-chave: lírica moderna; crônica brasileira; Rubem Braga; Paulo Mendes Campos. 


\begin{abstract}
One of the foundations of the chronicle genre is the subjectivity that pervades its stories. Among the several writers active during the 50's and 60's in the space of the Brazilian chronicle (the most creative decades within this literary genre if we take into account the shades of humor as well as the most intimate sensitivity), Rubem Braga and Paulo Mendes Campos stand out for the extent of their perceptions expressed in the text. The present work analyses some features of the lyrical operation performed by both writers in a time when human goals diverged from the delicate and fragile matter. On valuing exactly these aspects of life and pondering over their new senses, Paulo and Rubem redefine the sense of the modern lyric, adjusting its literary procedures to the crises of the individual and to the modifications of the individual expression.

Keywords: modern lyric; Brazilian chronicle; Rubem Braga; Paulo Mendes Campos.
\end{abstract}

\title{
REFERÊNCIAS
}

ADORNO, T. W. Notas de Literatura I. Trad. Jorge Almeida. São Paulo: Duas Cidades/Ed. 34, 2003.

ARRIGUCCI Jr., Davi. Fragmentos sobre a crônica. In: Enigma e comentário: ensaios sobre literatura e experiência. São Paulo: Companhia das Letras, 1987. p. 51-66.

BANDEIRA, Manuel. Estrela da vida inteira. 16. ed. Rio de Janeiro: José Olympio, 1989.

BENJAMIN, Walter. O narrador. Considerações sobre a obra de Nikolai Leskov. In: Obras escolhidas. Magia e técnica, arte e política. Trad. Sergio Paulo Rouanet. 5. ed. São Paulo: Brasiliense, 1992. p. 197-221.

BETELLA, Gabriela Kvacek. Sete faces para Rubem Braga. D. O. Leitura, n. 5, ano 22, nov./ dez. 2004.

BRAGA, Rubem. As meninas. In: . A traição das elegantes. 5. ed. Rio de Janeiro: Record, 1998. p. 76-78.

Ao respeitável público. In O conde e o passarinho e Morro do isolamento. Rio de Janeiro: Editora do Autor, 1961. p. 22-25.

CAMPOS, Paulo Mendes. Receita de domingo. In: Editora do Autor, 1960. p. 41-44. . O cego de Ipanema. Rio de Janeiro: Grande sertão: veredas. In: . cego de Ipanema. Rio de Janeiro: Editora do Autor, 1960. p. 31-33. p. $15-18$.

Ser brotinho. In O cego de Ipanema. Rio de Janeiro: Editora do Autor, 1960.

Na praia. In: O cego de Ipanema. Rio de Janeiro: Editora do Autor, 1960. p. 
BETELLA, G. K. O LiRISMO No Limite..

107-109.

No lotação. In: . O cego de Ipanema. Rio de Janeiro: Editora do Autor, 1960. p. $111-113$. $\overline{175-176}$

Segredo. In: ___ o cego de Ipanema. Rio de Janeiro: Editora do Autor, 1960. p.

CANDIDO, Antonio. A vida ao rés-do-chão. In: 1993. p. 23-29.

Dois cronistas. In: 2002. p. 205-210.

SANTOS, Joaquim Ferreira dos. Feliz 1958: o ano que não devia terminar. 5. ed. Rio de Janeiro: Record, 1998.

Enviado em: 28/10/2009

Aceito em: 11/01/2010 